\title{
A CERÂMICA DO ENGENHO INHAMÃ, IGARASSU-PE: UMA ANÁLISE SOB A PERSPECTIVA DA PRODUÇÃO AÇUCAREIRA E DAS RELAÇÕES COMERCIAIS
}

\author{
Pedro Paulo Dantas Sobral \\ Rafaela Torres Simões Faustino ${ }^{i}$ \\ Rebeka Wanessa de Andrade Silvaii \\ Cláudia Alves de Oliveiraiii
}

\begin{abstract}
Resumo: Este artigo trata dos aspectos relacionados às formas e funções da cerâmica utilizada na produção do açúcar no Engenho Inhamã, localizado no município litorâneo de Igarassu, Estado de Pernambuco. A intenção é apresentar um quadro interpretativo acerca do volume e qualidade do açúcar produzido, a partir das análises tipológicas e morfológicas dos vestígios cerâmicos resgatados nas campanhas arqueológicas empreendidas no Engenho. Neste contexto, informações de natureza marítimo-comercial foram abordadas como forma de auxiliar no entendimento da logística de compra e venda do açúcar em âmbito intercontinental. Palavras-chaves: Engenho Inhamã, cerâmicas do açúcar, colônias portuguesas, produção, comércio marítimo.
\end{abstract}

Abstract: This article deals with the aspects related to the forms and functions of the ceramics used in sugar production in the Inhamã Sugar Mill, located in the coastal municipality of Igarassu, in the state of Pernambuco. The intention is to present an interpretative table about the volume and quality of the sugar produced, from the typological and morphological analyzes of the ceramic traces recovered in the archaeological campaigns undertaken in this sugar mil. In this context, information of maritime-commercial nature was approached as a way to assist in the understanding of logistics of buying and selling of sugar in an intercontinental scope. Keywords: Inhamã Sugar Mill, sugar ceramics, portuguese colonies, production, maritime trade

\footnotetext{
i Mestre em Arqueologia pela Universidade Federal de Pernambuco - UFPE

ii Discente do mestrado em Arqueologia do Programa de Pós-Graduação em Arqueologia da Universidade Federal de Pernambuco

iii Docente do Departamento de Arqueologia da Universidade Federal de Pernambuco
} 


\section{Introdução}

Os primeiros registros do contato humano com a cana-de-açúcar antecedem à Era Cristã, e remetem à Nova Guiné, seguido da Índia e da China (Oliveira, 2010). A historiografia conta que em 327 AC, Alexandre Magno, ao invadir a Índia, verificou que os habitantes daquela zona mastigavam um vegetal que "produzia uma espécie de mel sem ajuda de abelhas". Desde então, com a expansão do "mundo árabe", o vegetal e as técnicas de produção do açúcar expandiram-se por toda a região do Oriente Médio sendo, posteriormente, introduzida na Europa, pontualmente na Andaluzia (Morgado, 2006). No século XIV a região Mediterrânea já possuía terrenos plantados com o vegetal, porém em quantidades que não sustentavam a demanda do açúcar, levando os europeus a importarem o produto do Oriente (Oliveira, 2010:35).

A princípio a cana era utilizada em seu aspecto natural, extraindo-se o suco que era utilizado fresco ou fermentado; o açúcar, propriamente, surgiria muito mais tarde. Os árabes trouxeram a cana sacarina do Oriente e introduziram-na no norte Africano e na Europa Mediterrânea, havendo referências de que no ano 912, a costa sul da Península Ibérica estava coberta de canaviais de onde se produzia açúcar sólido, inclusive para exportação (Ferrão, 2005 apud Oliveira, 2010:35).

Em meados do século XVI, o açúcar já era considerado a base do sistema comercial entre África, América e Europa (Figura 1). A rota comercial se iniciava em Lisboa, de onde os navios rumavam para a África com produtos manufaturados. De lá seguiam para o Brasil com escravos e produtos diversos, retornando em seguida para a Europa com o açúcar brasileiro (Oliveira, 2010:39).

No Brasil, os produtores de açúcar vendiam os seus produtos a preços baixos e, contrariamente, compravam as mercadorias vindas da Europa a preços altos, criando dívidas com os negociantes que serviam à Metrópole, que já obtinha grandes lucros com a venda do açúcar brasileiro. Além disto, Portugal também arrecadava grandes valores com a venda de escravos e o fornecimento destes aos senhores de engenhos e lavradores de cana nas suas colônias. Com tantas atividades lucrativas e a aprovação do açúcar brasileiro no mercado interno europeu, Portugal ganhava ascendência comercial, passando a incentivar a produção nos engenhos da sua colônia tropical americana (Oliveira, 2010:44). 


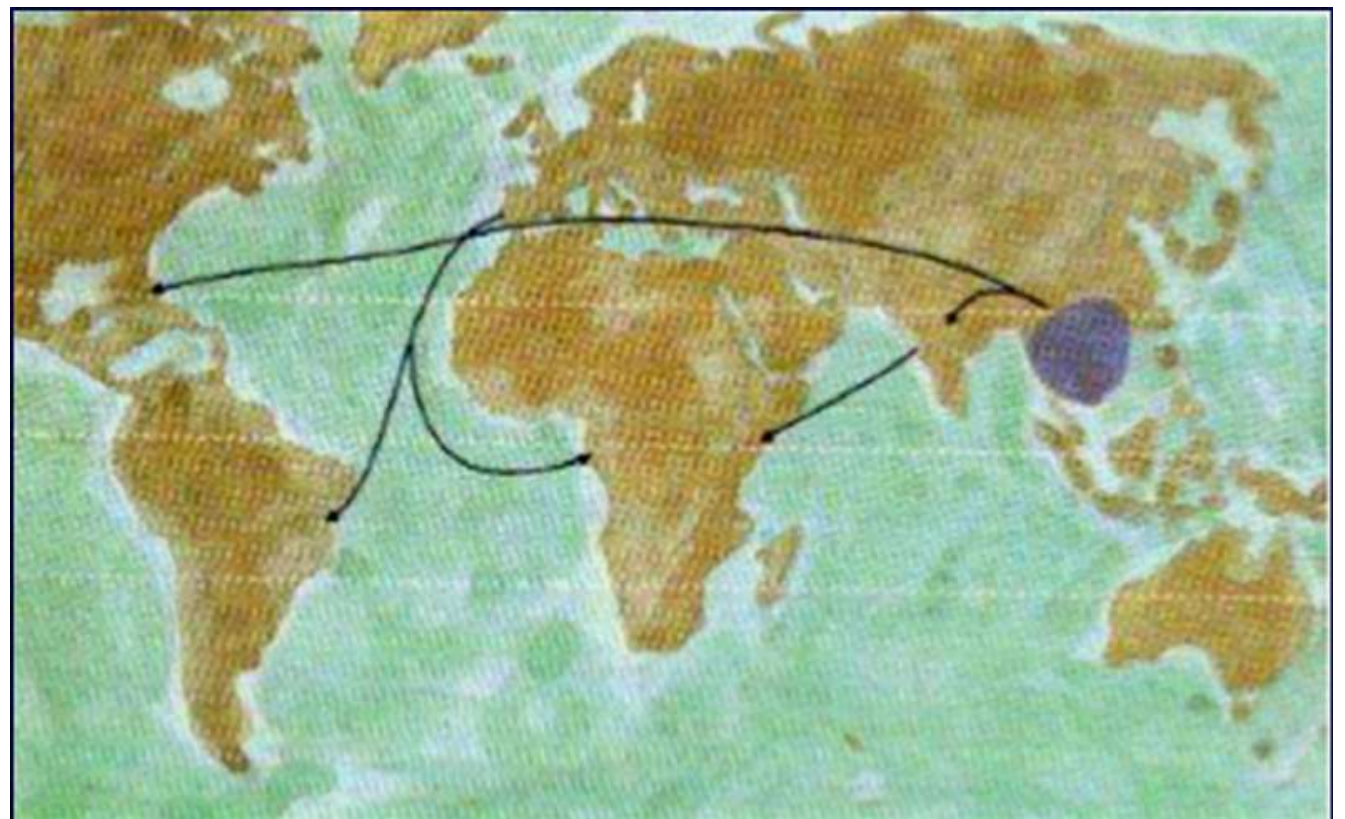

Figura 1: Mapa da difusão da cana-de-açúcar. Fonte: Ferrão, 2005 apud Oliveira, 2010.

Os engenhos de cana-de-açúcar são, certamente, a comprovação da primeira atividade industrial no Brasil. Até a atualidade, tipologias de vestígios de arquitetura colonial e de cerâmicas específicas voltadas para a produção do açúcar e do melaço, auxiliam na elucidação das etapas e procedimentos adotados na fabricação desses produtos. Segundo Cristina Menenguello, presidente do Comitê Brasileiro de Preservação do Patrimônio Industrial, "os engenhos podem ser considerados patrimônio industrial porque, embora não se refiram ao período da Revolução Industrial ou mesmo posterior, são registros do trabalho humano, do maquinário, das ferramentas e processos de produção que consideramos patrimônio industrial" (Mariuzzo, 2006 apud Pereira, s.d.:1).

Os engenhos funcionavam de três maneiras: com rodas d'água (engenhos reais), escravos e força animal (engenhos trapiches). De acordo com Gomes (2006), alguns engenhos funcionavam com dois tipos de força motriz. No Brasil, muitos engenhos foram construídos próximos ao litoral, visando escoar o açúcar com maior rapidez. Em Pernambuco, devido às condições favoráveis à navegação de barcaças $^{1}$ oferecidas aos engenhos pela sua malha hidrográfica, a maioria deles era movida pelas águas dos rios. Neste contexto, os engenhos eram estrategicamente estabelecidos de forma a aproveitar o curso das águas fluviais, seja para a força motriz, necessária para fazer girar as engrenagens extratoras do caldo da cana,

\footnotetext{
${ }^{1}$ Embarcação de fundo chato, pouco calado, medindo de boca aberta, com uma cabine abaulada à proa que lhe dá um aspecto de chinelo, e um convés à popa. Arma dois mastros onde enverga latinos quadrangulares com retranca [...]. O leme é de cana [...] (Cherques, 1999:102).
} 
seja para o embarque das caixas de açúcar, desembarque de mercadorias diversas e pessoas vindas dos mais variados lugares (Jordão, 1977:104).

A denominação "engenho" está presente em todos os estados brasileiros, contudo, em Cabo Verde, na África, ainda se utiliza o termo "trapiche" sendo interpretado como o espaço industrial destinado à produção (Nunes, 2006; Sanches, 2005). No Brasil, o termo trapiche engloba desde instalações de produção do açúcar, até armazéns de estocagem e local de embarque de mercadorias associadas ao comércio açucareiro (Sanches, 2005 apud Oliveira, 2010:55).

Portugal já possuía experiência na produção do açúcar em larga escala, além de contatos comerciais que permitiam a inserção do produto no mercado europeu. Esse relacionamento com o mundo financeiro da época, sobretudo com genoveses e flamengos, the permitiu a concessão de linhas de crédito para novos investimentos (Oliveira, 2010:44).

A partir da experiência adquirida nas Ilhas da Madeira, Açores e Cabo Verde, Portugal conseguiu inserir com êxito a cultura da cana sacarina no Brasil, que passava a ser seu maior e melhor produtor, a ponto de sustentar as bases da exploração colonial e do enriquecimento europeu, entre os séculos XV e XVII. Este processo comercial resultou no intercâmbio de mercadorias diversas entre continentes, bem como na presença massiva do colonizador no povoamento da nova colônia, dando origem a uma forte miscigenação cultural no Brasil (Oliveira, 2010:48).

No século XVI foi dado inicio, a partir do litoral norte de Pernambuco, a colonização das novas terras portuguesas. Anteriormente, até o ano de 1535, a principal atividade econômica era a extração do pau-Brasil, que ocorria entre a llha de Itamaracá e Igarassu. Nesta fase foi iniciado o processo de doação de terras e a implantação dos primeiros engenhos para a produção de açúcar da Colônia. Dos 120 engenhos moentes no Brasil, no ano de 1584, 66 estavam instalados em Pernambuco (Oliveira Lima, 1997:33).

Conforme Oliveira Lima (1997:55), mesmo com o advento da atividade açucareira, os donos de engenhos estavam diante de uma realidade comercial que precisava ser analisada devido às condições de transporte do açúcar, principalmente para os donos de engenhos, cujas propriedades não possuíam rios. Nesses casos, era preciso recorrer ao uso de carroças puxadas por animais até o porto fluvial mais próximo que, geralmente, pertencia a algum outro 
engenho e, por sua vez, cobrava pelos serviços prestados. Assim, o açúcar era transportado até a costa, onde era reembarcado para os navios fundeados naquelas proximidades (Figura 2).

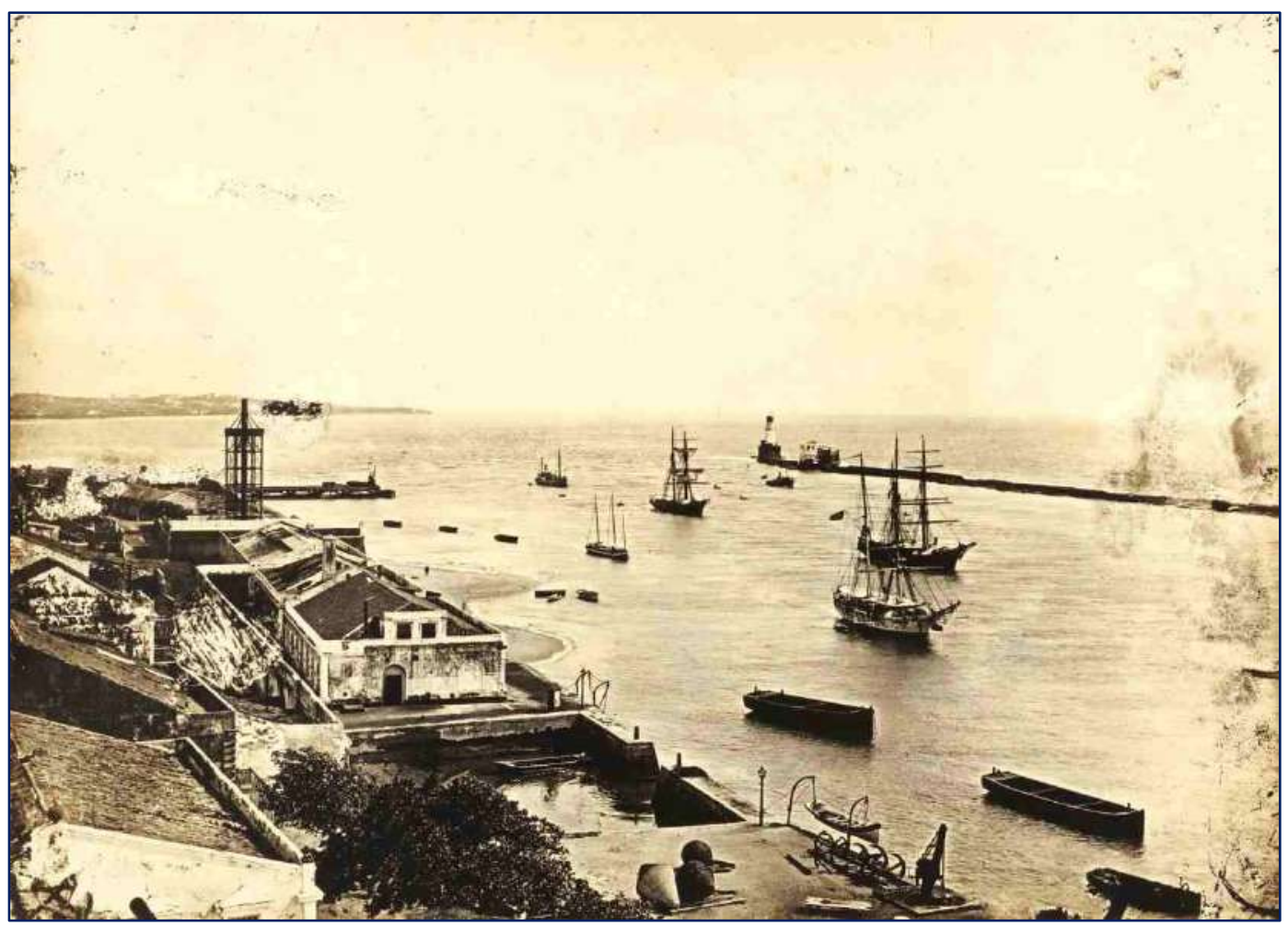

Figura 2: Fundeadouro do cais do porto do Recife- PE (anos de 1900). Fonte: Sobral, Tavares \& Rios, 2018:124

De acordo com Simonsen (1977), tem-se como ciclo do açúcar o período que vai do início da colonização até 1760. Esse período inclui o chamado "século do açúcar", isto é, 1570-1670, momento de intensa produção e lucratividade do negócio açucareiro. A partir de 1670 o valor exportado sofre quedas acentuadas e, em 1760, no auge do ciclo do ouro, inicia-se uma fase de expressiva decadência da cana, cujo total das exportações chegou a representar apenas $60 \%$ do que outrora havia sido comercializado no auge do "ciclo". Sendo assim, pode-se perceber um movimento de ascensão, auge e declínio do açúcar entre 1536-1760 (Fausto, 2006 apud Oliveira, 2010:49). Neste contexto de produção vamos encontrar o engenho Inhamã, um dos cinco primeiros engenhos instalados na Capitania de Pernambuco.

\section{O Engenho Inhamã}

Na Zona da Mata norte de Pernambuco, especialmente no município de Igarassu, alguns engenhos se destacaram pela capacidade de produção, dentre os quais está o engenho Inhamã, onde as atividades de produção, provavelmente, iniciaram nos meados do século XVI, 
na área da antiga Sesmaria Jaguaribe, doada por Duarte Coelho a Vasco Fernandes em 1540. No livro de Denunciações e Confissões de Pernambuco 1593/95 consta que era de propriedade de Antônio Jorge e Maria Farinha, possuindo uma área de "800 braças de quadra", até que foi desmembrado e doado aos jesuítas do colégio de Olinda para posterior construção do engenho Monjope (Neto, 2007 apud Pereira, s.d.:06).

Do ponto de vista geológico, o sítio arqueológico engenho Inhamã pertence à unidade estratigráfica da Formação Barreiras, presente na Mesorregião metropolitana do Recife, litoral norte de Pernambuco (Figura 4). Geograficamente esta unidade concentra sua área de afloramento em grande parte da porção norte da Região Metropolitana do Recife (RMR) e em parte da planície do Recife.

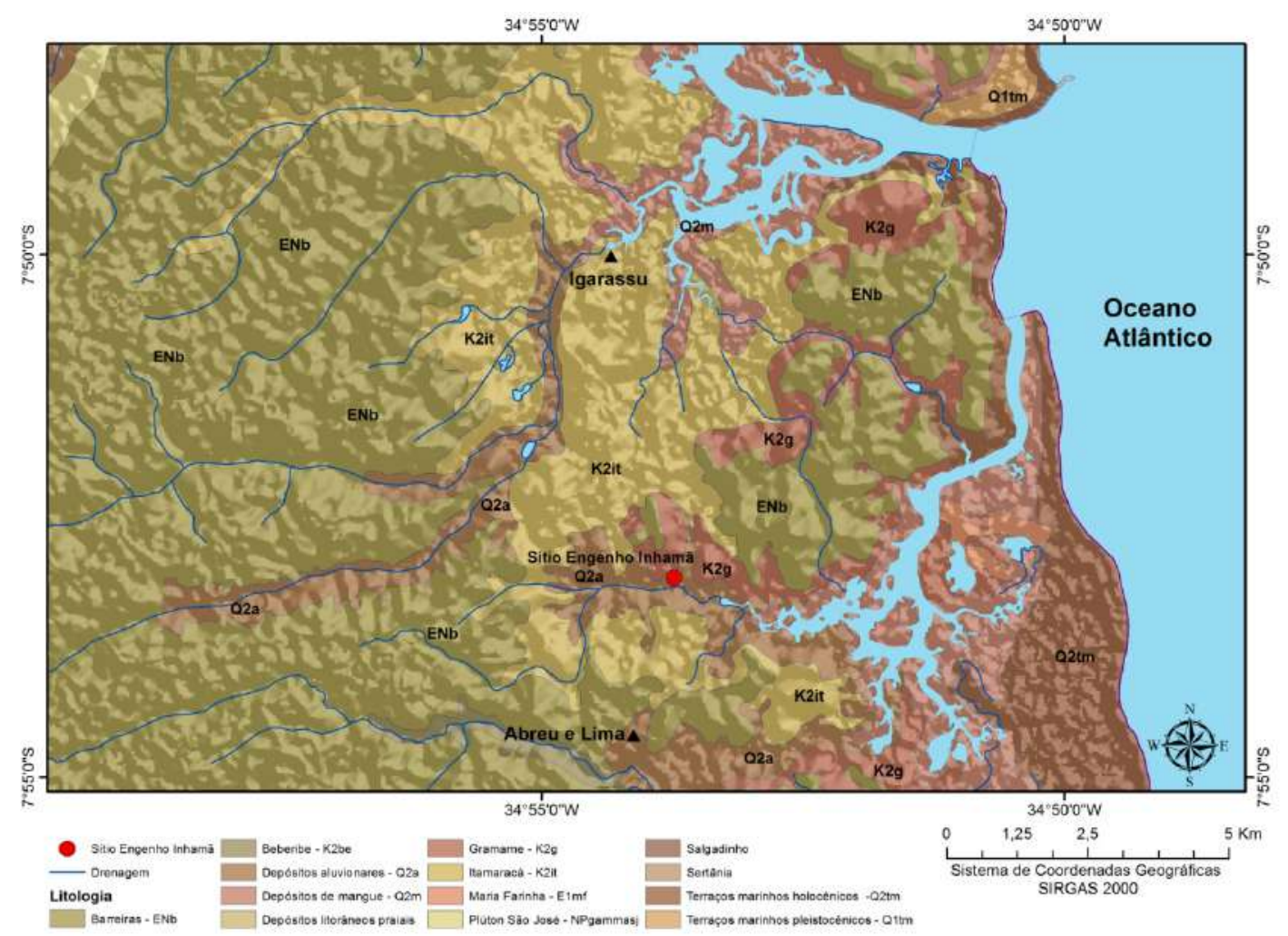

Figura 3: Localização da área de pesquisa. Fonte: Silva et al 2017

As pesquisas arqueológicas realizadas no Engenho Inhamã, foram iniciadas 2001, através do projeto Prospecção de Sítios Arqueológicos da Sesmaria Jaguaribe, área dos atuais municípios de Abreu e Lima, Paulista e Igarassu. Posteriormente, a partir de um estudo específico sobre a produção de açúcar em Pernambuco, as pesquisas continuaram através do projeto Os Primeiros Engenhos Coloniais da Sesmaria Jaguaribe - PE. Essas pesquisas continuam gerando novos dados arqueológicos até os dias atuais, trazendo uma série de questões decorrentes do 
período em que o açúcar era a principal base econômica de Pernambuco. Desde então foi possível elucidar questões relacionadas ao preparo do açúcar, mão-de-obra condizente, comercialização do produto, interação sociocultural entre diferentes grupos de origem indígena, europeia e africana, além da expansão das atividades açucareiras nos séculos XVII, XVIII e XIX (Magnavita et al. 2016:09; Oliveira, 2018:17).

Atualmente está sendo realizado o projeto "Arqueologia e Acessibilidade do Engenho Jaguaribe no Litoral Norte de Pernambuco", com o apoio do Funcultura, Prefeitura do Município de Abreu e Lima e Universidade Federal de Pernambuco-UFPE, e tem por objetivo geral caracterizar o engenho do século XVI, reconhecendo seu modelo de implantação e as definições de suas estruturas arquitetônicas.

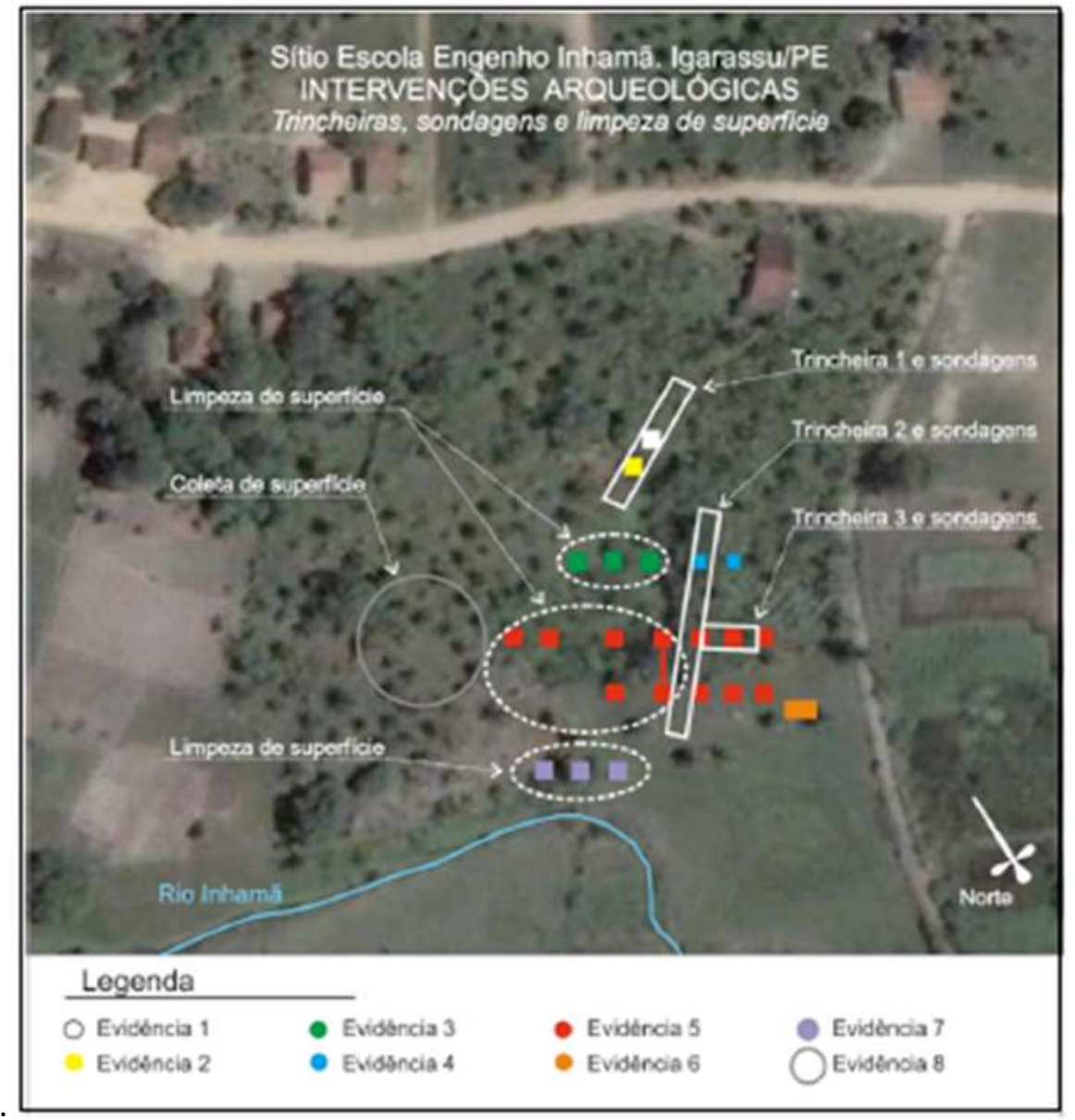

Figura 4: Ilustração das intervenções arqueológicas aplicadas. Fonte: Oliveira \& Lara, 2012:21.

A escavação no Engenho Inhamã foi iniciada em agosto de 2008, onde foram abertas duas trincheiras, nas proximidades de estruturas edificadas, divididas por quadrículas de $2 \times 2$ 
metros (Figura 4). As quadrículas foram escavadas de modo alternado, semelhante a um tabuleiro de xadrez e teve o objetivo de identificar a relação entre as construções, suas dependências internas e seu entorno imediato (Oliveira \& Lara, 2012:21).

Como resultado dessa pesquisa foram evidenciados: fragmentos de cerâmica, utensílios líticos, estruturas arquitetônicas em alvenaria de pedra talhada e argamassa, estruturas em alvenaria de tijolo cerâmico maciço e argamassa, reboco com colunas e bases interligadas entre si, e uma área com grande concentração de fragmentos cerâmicos reconhecidos como fôrmas de açúcar, objeto de estudo desta pesquisa. Procura-se, portanto, caracterizar as fôrmas de açúcar do engenho Inhamã e avaliar a capacidade produtiva e do nível de refinamento do açúcar comercializado em suas dependências.

\section{A utilização e a produção da cerâmica do açúcar}

A cerâmica do açúcar é um termo proposto por pesquisadores espanhóis e portugueses, desde o século XVI, para denominar as peças empregadas em diversas etapas do processo de produção do açúcar. Os principais objetos utilizados nesse processo são as fôrmas, os sinos e os porrões, desempenhando, cada um, função específica referente a uma etapa do processo de produção. Ainda, segundo Andrés et al., (2017:02), as peças que formam a cerâmica do açúcar não apresentam características tipológicas bem definidas entre si, tendo as suas dimensões, na maioria das vezes, como principal elemento norteador na classificação e, consequentemente, na realização de inferências quanto à funcionalidade dos objetos.

O tipo existe, conforme Clarke (1984), em função dos atributos considerados importantes para se estabelecer uma classificação. Assim, o tipo seria uma população homogênea de artefatos, com semelhanças de atributos sistematicamente recorrentes em um determinado conjunto. Isto implica dizer que os artefatos e objetos que coincidem em algumas características são parte de um grupo classificatório denominado tipo (Eiroa et al. 1999).

As fôrmas possuíam forma cônica, um furo no vértice e serviam, basicamente, como moldes para a confecção dos pães de açúcar ou pilões, que eram extraídos ou separados, segundo as diversas qualidades do açúcar produzido - branco, quebrado, de segunda etc. - para serem organizados em caixas de madeira destinadas à exportação (Andrés et al. 2017:01). Suas dimensões, contudo, não seguiam padrões específicos, podendo possuir altura e largura variantes (Figura 5). 


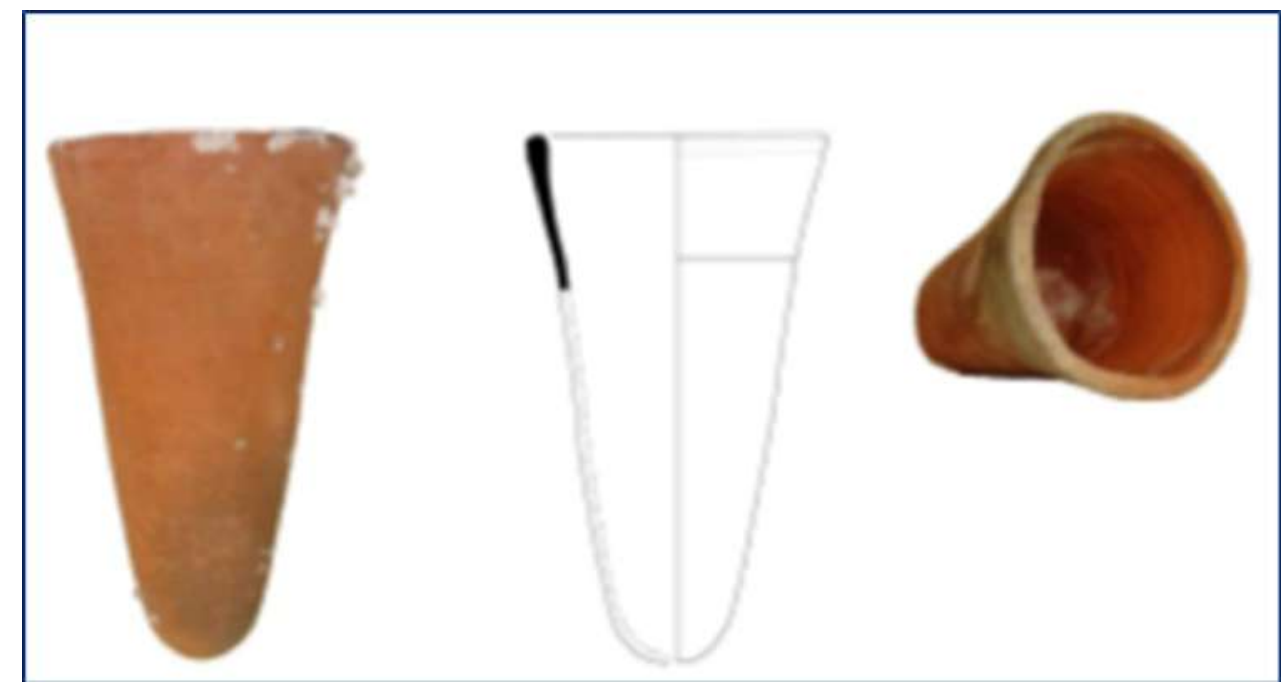

Figura 5: Fôrma de pão de açúcar em 2D, 3D e reconstituição a partir de fragmento borda-bojo. Fonte: Rocha \& Morgado, 2014:101.

Os sinos, tipologicamente, são similares às fôrmas, diferenciando apenas nas dimensões, geralmente superiores na altura e no diâmetro da boca. Segundo o arqueólogo português Élvio Duarte Martins Sousa, os sinos custavam ser mais caro aos engenhos, uma vez que eram maiores e permitiam aumentar a produção, além de possuírem melhor acabamento e borda emoldurada para facilitar a sua instalação nos andaimes de madeira destinados a sustentar as peças cerâmicas postas à purgação (Sousa, 2008 apud Andrés et al. 2017:04).

O termo sino, ou sino de mel, foi atestado inicialmente nas ilhas da Madeira e Canárias, na primeira metade do século XVI, tornando-se um termo específico da atividade açucareira para designar uma fôrma de açúcar grande (por analogia com a campânula do sino de bronze das igrejas). Posteriormente, o termo sino difunde-se no Atlântico, Cabo Verde, São Tomé e Príncipe, Brasil e América Espanhola. A forma cônica revelada pelo nome sino parece indicar que este tem a mesma função da fôrma de açúcar, apresentando um furo no fundo para purgar o açúcar, separando-o do mel (Nunes, 2009 apud Oliveira, 2010:62).

Os porrões, de acordo com Élvio de Sousa (2005:15), eram receptáculos cerâmicos, de base plana e sem orifícios, boca larga, bojo ligeiramente estrangulado e paredes levemente curvadas. Sua função era servir de apoio para as fôrmas de açúcar e recolher o melaço resultante do processo de purga. Essencialmente eram objetos cerâmicos que não necessitavam de uma morfologia especial, desde que possuíssem uma boca larga o suficiente para dar estabilidade no momento de receber a fôrma de pão de açúcar. 
O termo porrões aparece pela primeira vez como terminologia ligada à produção açucareira em Valência, no ano de 1415 , com a designação de porrons. Na documentação da ilha da Madeira, apenas aparece o termo "jarros de castella" com o mesmo significado, tal qual consta no Testamento de António Teixeira, de 1535: "2 tinas grandes de cedro de receber o mel, 2 coxos grandes de ter mel, 3 jarros de castella de recolher o mel" (Morgado, 2006:07).

Os sinos e os porrões estabeleciam uma relação de dependência no tocante à função, uma vez que, caso não houvesse um perfeito encaixe entre as peças, o processo de purga não seria satisfatório, em função de algum desequilíbrio das partes (Figura 6).

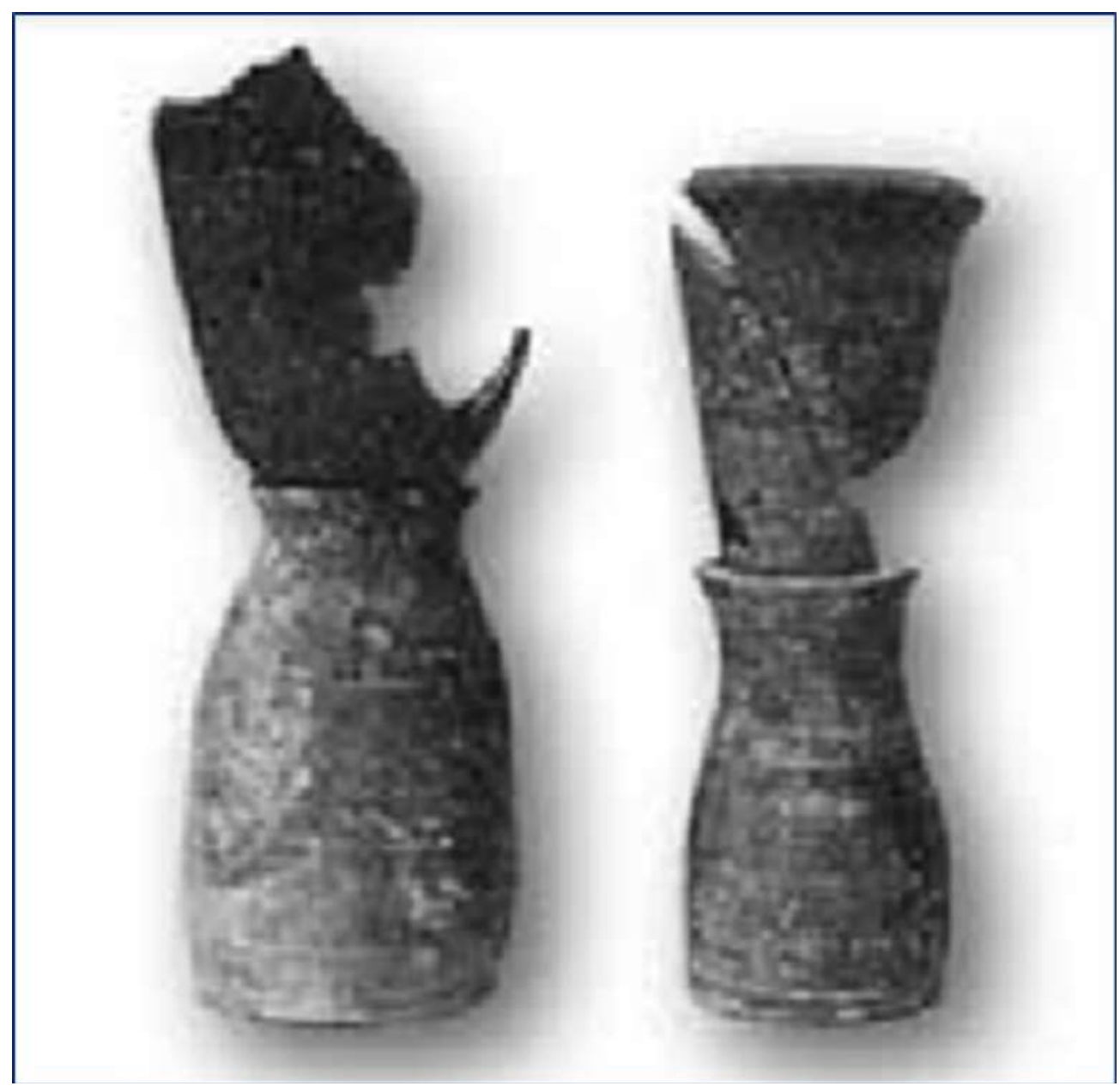

Figura 6: Reconstituição física de parte de sinos em seus devidos porrões. Fonte: Sousa, 2006:18.

No que tange às etapas de produção do açúcar, Giulio Landi, em visita à ilha da Madeira, em 1530, deixou um registro impresso com detalhes técnicos:

Os lugares, onde com muito grande diligência e arte, se faz o açúcar, são as grandes quintas. $O$ modo é o seguinte: Primeiro, trazidas para os referidos 
lugares as canas cortadas, põem-nas sob uma mó movida a água, que, premindo e destroçando as canas, faz sair delas todo o seu sumo. Aqui há cinco recipientes, postos por ordem, a cada um dos quais se passa por uma conduta o sumo, que sai das canas. Conduzido ao primeiro recipiente, deixase ferver até certo limite de tempo e de cozedura; depois, passando de mão em mão para os outros recipientes, com fogo brando, dá-se-lhe com arte a cozedura; até que ele fique tão espesso que, colocado nas formas de terra, se possa endurecer. A espuma que se faz ao cozer o açúcar repõe-se nos tonéis, excepto a que sai da primeira cozedura, que se deita fora; mas a outra, que se conserva, é semelhante ao mel, embora um pouco mais negra e líquida; e é chamada pelos da terra, melaço. (Morgado, 2006:06).

À etapa de produção à qual as fôrmas eram utilizadas denomina-se secagem, momento em que a massa de açúcar cozinhado era colocada cuidadosamente nas peças cerâmicas para que acontecesse o escorrimento do mel por decantação, e, posteriormente, a cristalização (Andrés et al. 2017:07).

Para a secagem (Antonil, 1711) a massa era pesada e colocada nas fôrmas até atingir o ponto de consistência ideal. As fôrmas podem ser definidas como vasos de barro queimado na fornalha das telhas, tendo alguma semelhança com os sinos. Possuem menor circunferência na boca e são mais apertadas no vértice, aonde são furadas para que se consiga lavar e purgar o açúcar. Por este furo caem os resíduos de melado (Figura 7) (Centro de Estudos da História do Atlântico-CEHA, s.d. apud Oliveira, 2010:61).
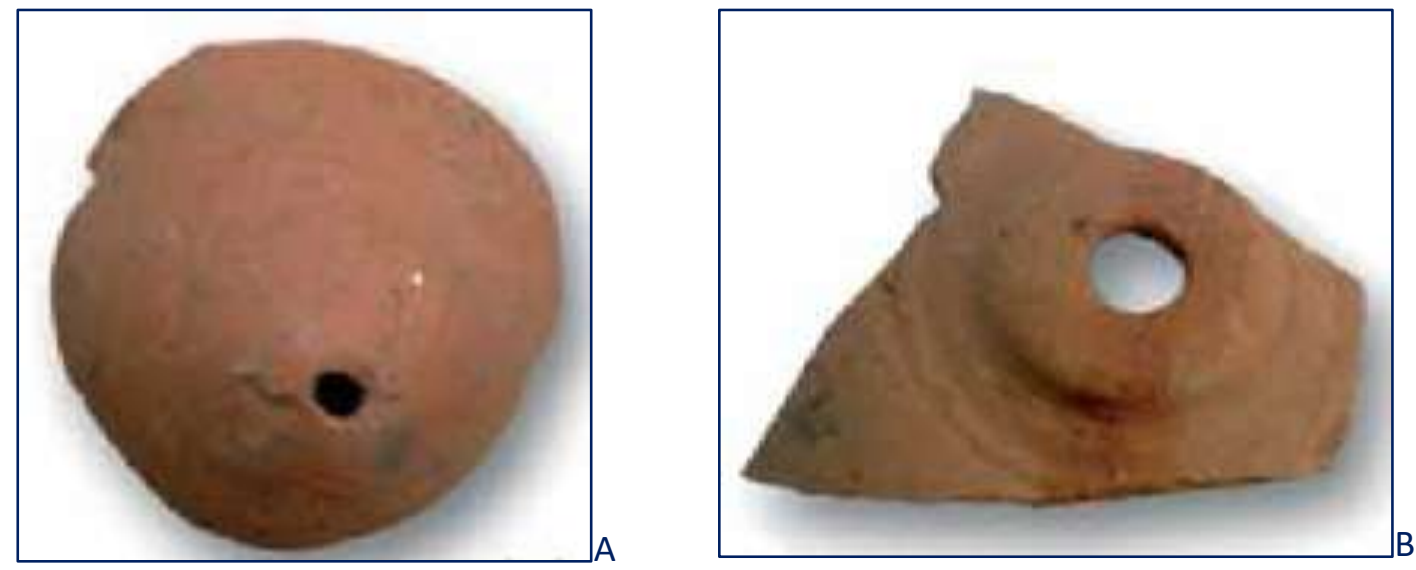

Figura 7 ( $\mathrm{A}$ e B): Orifícios presentes nos vértices das fôrmas e sinos para decantação da fase líquida do açúcar. Fonte: Sousa, 2006.

Uma vez seco e desenformado, obtinha-se o açúcar bruto ou mascavo, comercializado em pedaços ou submetido a clareamento, na produção do "açúcar Demerara". A transformação de mascavo em demerara era feita nos engenhos pelo processo de purgação. O local onde se estocava esse açúcar era chamado casa de purgar. A purgação era feita com água colocada 
sobre uma camada de argila aplicada sobre o pão de açúcar, e escoada pelo orifício inferior, levando as impurezas. Na casa de purgar, última fase da produção, a massa resultante do processo era purificada e dividida em pães de açúcar - forma em que o produto era comercializado (Oliveira, 2010:62).

É possível compreender que a morfologia do corpo tronco-cônico invertido e com uma perfuração na porção final da peça, era uma condição técnica no processo de cristalização e refinamento do açúcar, pois facilitava a expulsão das impurezas contidas no melaço e a própria retirada da parte sólida (pão de açúcar). Além disso, discute-se a hipótese de que o formato cônico da fôrma pudesse facilitar a logística de empilhamento e armazenamento do conteúdo açucarado nos lastros dos navios, sendo então o açúcar exportado ainda nas referidas peças em cerâmicas (Sarmento, 1938:430). Nesses casos, pode-se aventar a possibilidade de venda do açúcar juntamente com a peça cerâmica.

No Brasil, para a venda no mercado externo e desembarque nos portos, no entanto, era necessário triturar e secar os pães de açúcar ao sol para transportá-los em caixas. Os pães de açúcar depois de secos eram embrulhados em papel e colocados em caixas de madeira para se manterem intactos no percurso que os levaria ao destino de consumo (Oliveira, 2010:63).

A gravura elaborada por Stradanus (Figura 8), no século XVI, retrata as etapas do processo de produção, desde a cana até o açúcar:

\footnotetext{
"Após a entrada da cana, esta é limpa e cortada, passando depois para a moagem, neste caso realizado com auxílio de um moinho de água (azenha), de onde o produto moído é transportado para a prensagem. A calda obtida é cozinhada, sendo depois colocada em fôrmas cerâmicas, que tem seu grau de pureza avaliado em função do tempo de cozedura ou do número de vezes que vai a cozer. Por fim, desenformam-se os pães de açúcar" (Morgado, 2006:06).
} 


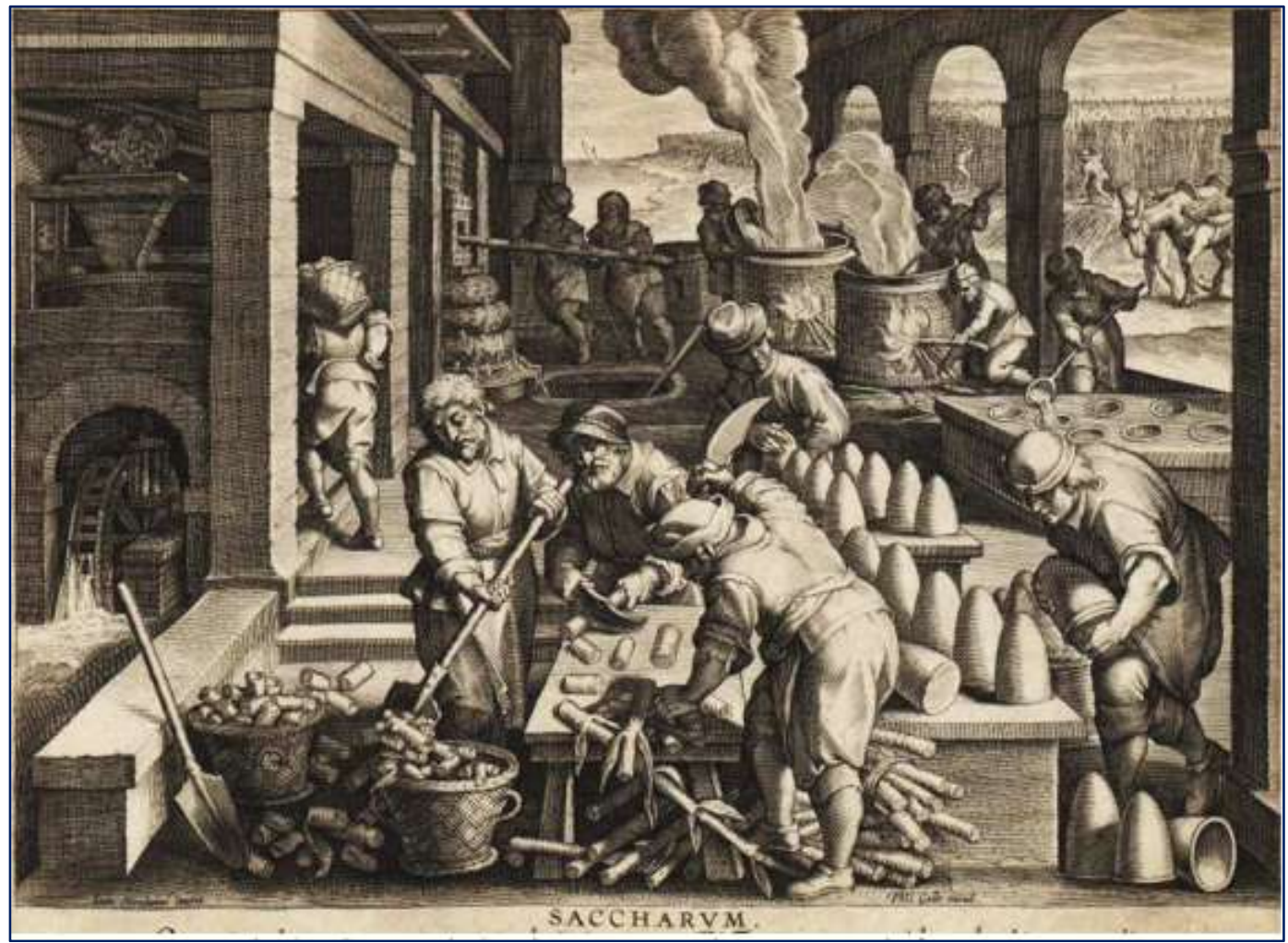

Figura 8: Gravura de Stradanus mostrando o processo de fazer açúcar. Fonte: Morgado, 2006:07.

Tanto na descrição de Landi como na gravura de Stradanus, o elemento fundamental da purga é a fôrma de açúcar, inserida tipologicamente na chamada "cerâmica do açúcar". Segundo Naidea Nunes, a primeira vez que aparece o termo fôrma ocorre nos inícios do séc. XV, na Sicília, como "zucchero cum furmis et cantarellis" em 1411, "forme di miele" ou "forme di zuccaro" em 1452, ou "furmas plenas zuccari mellis stantes subtus cretam" em 1443 (Morgado, 2006:07).

O Tractatus de Herbis de Dioscorides, datado do séc. XIV, apresenta uma gravura da fase da purga do açúcar, onde se verifica a utilização das fôrmas, apresentando já o típico formato cônico, muito próximo das mais recentes produzidas nas olarias portuguesas. A gravura mostra a metodologia de funcionamento desse sistema: a calda é introduzida na fôrma, que neste caso está suspensa por um suporte, escorrendo a sua fase líquida por gravidade, sendo expelida pelo orifício inferior onde é recolhida em um contentor denominado porrão. Em cima da mesa é possível observar dois pães de açúcar, já depois de desenformados (Figura 9) (Morgado, 2006:09). 


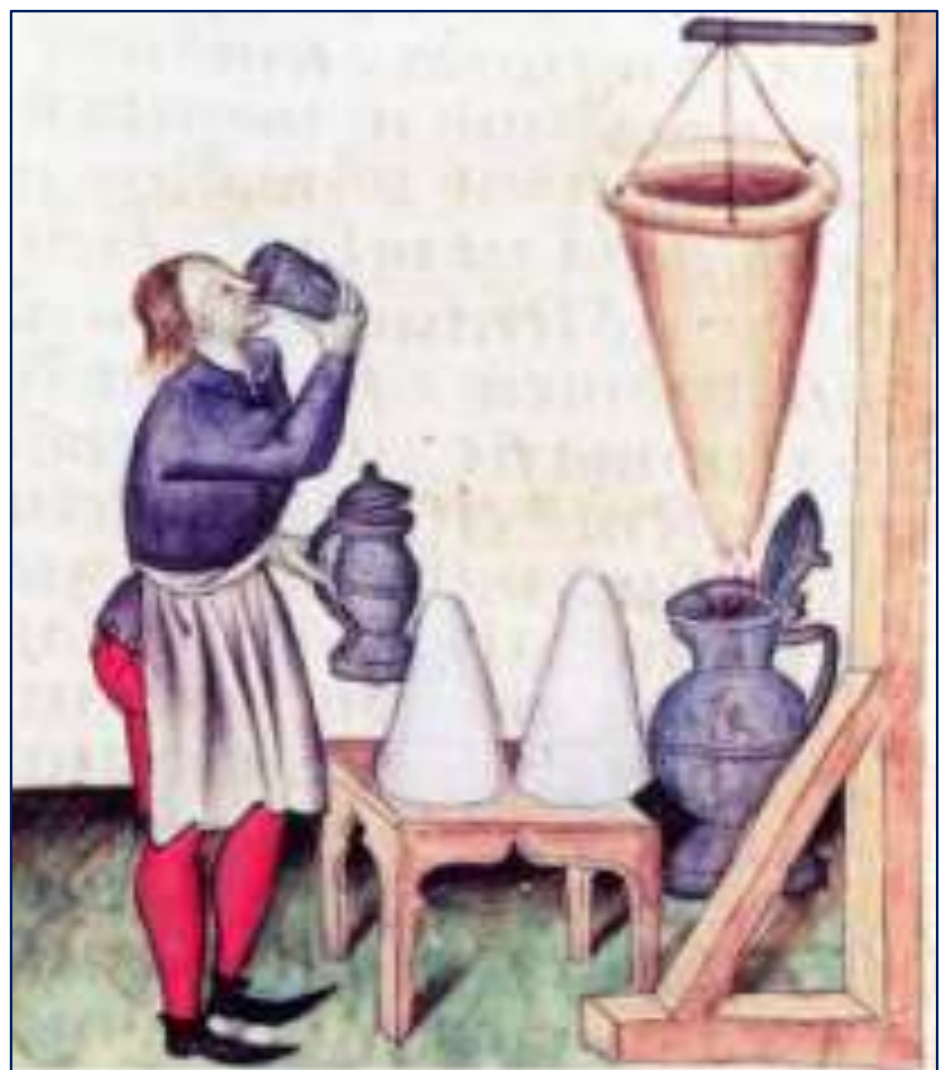

Figura 9: Desenho do século XIV retratando a purgação do açúcar. Fonte: Morgado, 2006:09.

Além da compreensão das morfologias e funções das cerâmicas relacionadas à produção do açúcar, é válido conhecer as principais áreas produtoras destas peças, de forma a criar um discernimento acerca da importância das fontes com boas argilas. Com isso, outros aspectos passam a ser avaliados involuntariamente, a exemplo da movimentação comercial na exportação e importação dos referidos objetos, bem como a durabilidade dos mesmos, além do custo de reposição que representavam para os engenhos. Contudo, em se tratando das cerâmicas do açúcar, não há, de fato, debates consensuais, seja sobre funções, dimensões, morfologias e, até mesmo centros produtores, o que faz com que os pesquisadores analisem de forma minuciosa a confiabilidade das fontes, a presença de documentação histórica, e a recorrência de dados em textos diversos, para então formalizarem suas inferências.

No estudo da tecnologia cerâmica para a produção das fôrmas de açúcar, informações sobre transformações térmicas são necessárias na elucidação dos avanços tecnológicos e das fontes de matéria-prima, assim como para identificar a composição das jazidas de argilas (Trindade et al. 2010 apud Rocha \& Morgado, 2014:100). Conforme Rocha e Morgado (2014:97), o processo de produção cerâmico é essencialmente térmico; produz mudanças de fases que tem as 
transformações mineralógicas como importante marcador de temperatura e de análises comparativas entre produto cerâmico e possível matéria-prima

Desde a Península Ibérica a cerâmica do açúcar era exportada para os arquipélagos de Madeira, Açores e Canárias, assim como para o continente americano, especialmente o Brasil. De acordo com Manuel Lobo Cabrera, as fôrmas foram, possivelmente, os objetos mais exportados por Portugal, entre 1560 e 1575, alcançando a quantidade aproximada de 13.850 dessas peças produzidas em Aveiro. Dali também se exportavam os sinos, em menor quantidade, porém agregando maior valor. Em Portugal, os principais centros oleiros de peças cerâmicas, utilizadas na produção do açúcar, se concentravam na região de Aveiro, seguidos das localidades de Atouguia e Santo Antônio da Charneca. Bairro das Olarias, Travessa das Olarias ou Rua dos Barreiros são denominações de zonas e ruas da cidade de Aveiro que confirmam que a localidade era forte produtora de peças cerâmicas em meados do século XVI (Nobre, Faria \& Velosa, 2017:03). Na Espanha, os centros produtores seriam Sevilha, Granada e Manises. (Andrés et al. 2017:03).

Em Santo Antônio da Charneca, no ano de 1997, foram identificados vestígios de uma antiga olaria, encontrados no interior de valas abertas para a colocação de manilhas em obras de urbanização. Entre as peças recolhidas destaca-se um significativo conjunto de fragmentos de fôrmas de pão de açúcar. Essas fôrmas e também sinos foram encontrados em escavações arqueológicas realizadas em edifícios históricos de Aveiro (Conventos de Jesus e de Santo Antônio) e em restos de embarcações naufragadas na atual laguna, assim como no Bairro das Olarias, adjacente ao tramo sul da muralha da cidade (Rocha \& Morgado, 2014:101).

O comércio das fôrmas e sinos era uma realidade, já que alguns motivos podem justificar essa relação de compra e venda entre os núcleos oleiros e os engenhos compradores dessas cerâmicas. É possível citar a qualidade da argila e a espessura de algumas peças como principais responsáveis pela quebra constante, refletindo na necessidade de substituições. Entretanto, há relatos de que as fôrmas e sinos precisavam ser quebradas para a retirada dos pães de açúcar. Tal hipótese é levantada por Antônio Malpica Cuello, no texto apresentado no Segundo Seminário Internacional, intitulado A Cana de Açúcar no Mediterrâneo:

Todo parece indicar, según ya dijimos, que aquéllos se rompiam para obtener el pan de azúcar. No es, pues, extraño que las formas cerámicas hayan aparecido hasta el presente muy fragmentadas y la mayoría de los fragmentos acumulados (Cuello, 1990 apud Sousa, 2006:151). 
Verificando ainda o aspecto da fragmentação das fôrmas, Sousa (2006) lembra que, segundo Alberto Vieira (2000), no "fabrico do açúcar as fôrmas só serviam uma vez, necessitando quase sempre de ser partidas para retirar-Ihe o pão de açúcar." Apesar de haver referências de que as fôrmas de pães de açúcar passariam por um processo de preparação antes de sua utilização, com o objetivo de facilitar a separação do pão de açúcar das paredes internas das fôrmas. Portanto, nota-se neste processo algumas dificuldades enfrentadas na hora da retirada dos pães de açúcar, assim, as fôrmas eram imersas em uma solução de água e mel para facilitar o trabalho.

\section{As Fôrmas de Açúcar do Engenho Inhamã}

O ponto de partida desta pesquisa foi a criação de um quadro tipológico das fôrmas de açúcar encontradas no engenho Inhamã; neste sentido foi elaborado um protocolo com os atributos morfológicos, técnicos e funcionais. No primeiro aspecto foram considerados os tipos de bodas, bojos, bases, diâmetro da boca, altura da peça e a sua forma. Verifica-se que as bases planas caracterizam os porrões, importantes no aspecto qualitativo e quantitativo da produção. Esse tipo de vasilhame de contenção do melaço que vertia das fôrmas e sinos pode compor o quadro interpretativo da área destinada à purgação. A depender do diâmetro de abertura dessas peças, é possível inferir se as mesmas encaixavam-se às fôrmas (menores) ou aos sinos (maiores), e, por conseguinte, deduzir a qualidade do açúcar destinado à venda.

Assim, foram realizadas as descrições métricas, importantes nas respostas relativas à morfologia, uma vez que as fôrmas e os sinos, segundo a historiografia, eram muito similares, diferenciando-se apenas quanto às dimensões de altura e largura, bem como na etapa desempenhada nos procedimentos de obtenção de um açúcar mais escuro ou mais cristalino. Entre os aspectos técnicos foram considerados os atributos relacionados à cor, dureza, pasta, tipo de queima, tratamento de superfície e técnica de manufatura.

Especificamente neste trabalho, os dados métricos foram priorizados, ainda que a identificação do tipo de pasta auxilie na compreensão do uso das fontes de argila, e a morfologia das peças ofereça dados referentes aos volumes produzidos e à qualidade do açúcar finalizado.

Na coleção analisada, verifica-se um alto grau de fragmentação da cerâmica, e para se ter uma segurança maior sobre as peças que teriam sido fôrmas de açúcar, nesta etapa da pesquisa, 
foram selecionados os fragmentos de bordas e bordas com bojo, onde foram analisados o tipo e o diâmetro da boca. No total de 167 fragmentos, 98 são de bordas e 69 bordas com bojo (Tabela 1). Nesta amostra, 33 bordas e 4 bordas com bojo, não apresentaram os elementos necessários para a aferição do diâmetro da boca da peça, por conta do tamanho reduzido da corda. Apesar dessa limitação, as peças tinham plena condição de fornecer dados referentes à tipologia, estudo válido para a identificação da forma do objeto cerâmico.

Tabela 1: Morfologias e respectivas quantidades dos fragmentos analisados.

\begin{tabular}{l|l|c|c|c}
\hline \multicolumn{2}{c|}{ Morfologia } & Bordas & Borda/Bojo & Total \\
\hline \multicolumn{2}{c|}{ Quantidade - total } & 98 & 69 & 167 \\
\hline \multirow{2}{*}{ Tipos } & Reforçadas & 60 & 51 & 111 \\
\cline { 2 - 5 } & Diretas & 38 & 18 & 56 \\
\hline
\end{tabular}

O resultado da análise quantitativa em relação às bordas e às bordas com bojos, concluiu que as peças apresentaram, em sua maioria (111), algum tipo de reforço estrutural, enquanto que os sem reforço totalizaram 56 (Tabela 1). Isto indica que, provavelmente, os sinos eram mais utilizados que as fôrmas na produção do açúcar no engenho Inhamã.

Sousa $(2005 ; 15)$ informa que o arqueólogo Cláudio Torres, na divulgação da primeira tipologia sobre as fôrmas de açúcar na Mata da Machada, Barreiros, Portugal, apresenta duas variantes que puderam ser definidas: 1) a presença de peças menores, podendo conter 2,5 $\mathrm{kg}$ de açúcar; e 2) as peças de maiores dimensões, apresentando bordas de acabamento emoldurado e com uma capacidade para até $5 \mathrm{~kg}$ de massa açucarada. O reforço na estrutura do utensílio era, provavelmente, para facilitar a colocação das peças nas aberturas dos andaimes de madeira. 0 pesquisador também relata que em Machico, Portugal, foram identificadas várias morfologias cerâmicas que remetem à produção de açúcar, dentre as quais estão as de tamanho mais reduzido e sem reforço nas bordas, e as maiores, apresentando molduras salientes que acompanham as bordas.

Com base na perspectiva métrica apresentada, os fragmentos analisados no engenho Inhamã foram classificados em dois tipos:

Tipo 1 - para os que possuem diâmetro de abertura da boca variando entre $18 \mathrm{~cm}$ e $44 \mathrm{~cm}$; e 
Tipo 2 - para os que possuem medidas entre $46 \mathrm{~cm}$ e $62 \mathrm{~cm}$, compreendendo as medidas mínimas e máximas para todos os objetos que compõem a amostra estudada (Tabela 2).

Tabela 2: Morfologias e respectivos diâmetros de abertura da boca

\begin{tabular}{l|l|l}
\hline Classificação por tipos & \multicolumn{1}{|c|}{ Borda } & \multicolumn{1}{|c}{ Borda/Bojo } \\
\hline Tipo 1: $18 \mathrm{~cm}-44 \mathrm{~cm}$ & 57 & 47 \\
\hline Tipo 2: $46 \mathrm{~cm}-62 \mathrm{~cm}$ & 8 & 18 \\
\hline
\end{tabular}

Do ponto de vista da morfologia das peças e do seu enquadramento funcional nas etapas de produção do açúcar, as amostras do Tipo 1 não possuem, em sua maioria, bordas reforçadas e ainda apresentam diâmetro médio de $34 \mathrm{~cm}$ para a abertura do utensílio cerâmico. Tais peças configurariam as fôrmas utilizadas na produção de um açúcar mais refinado, denominado à época, açúcar Demerara. Nas fotos a seguir o diâmetro estimado para cada um dos dois fragmentos é de $38 \mathrm{~cm}$ (Figuras 10 a 13).
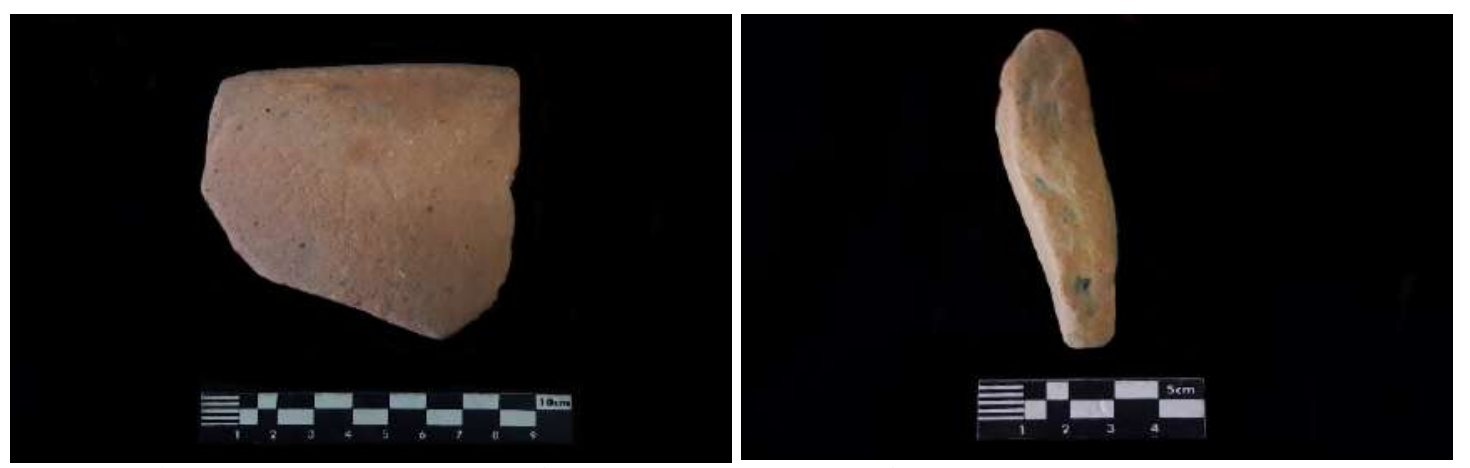

Figura 10: fragmento de borda direta (№ de registro IN.706.31).

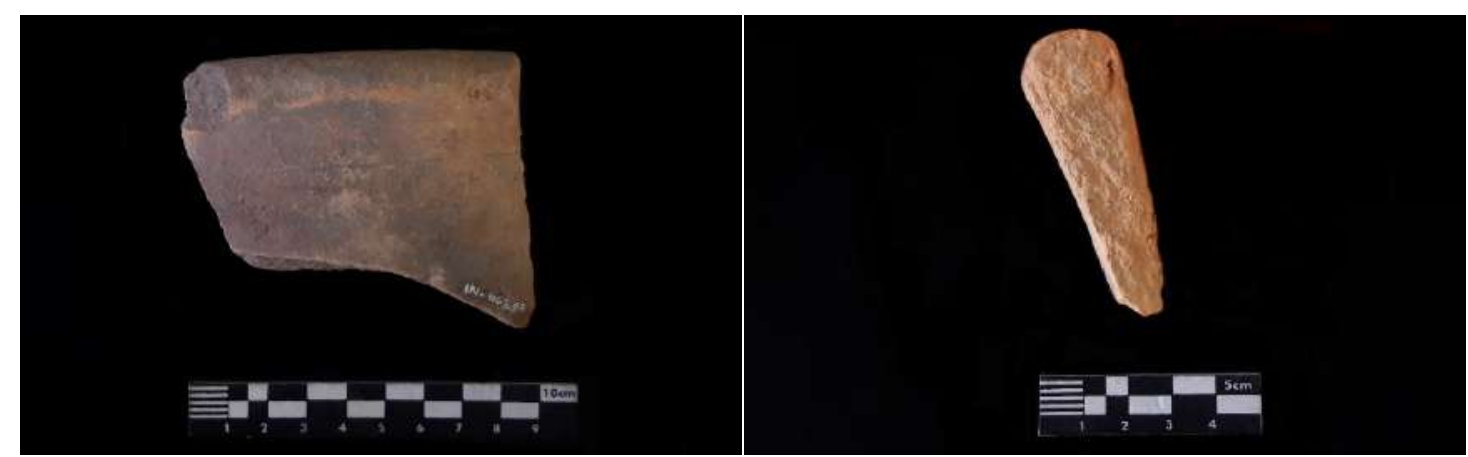

Figura 11: fragmento de borda direta (№ de registro IN.668.17). 

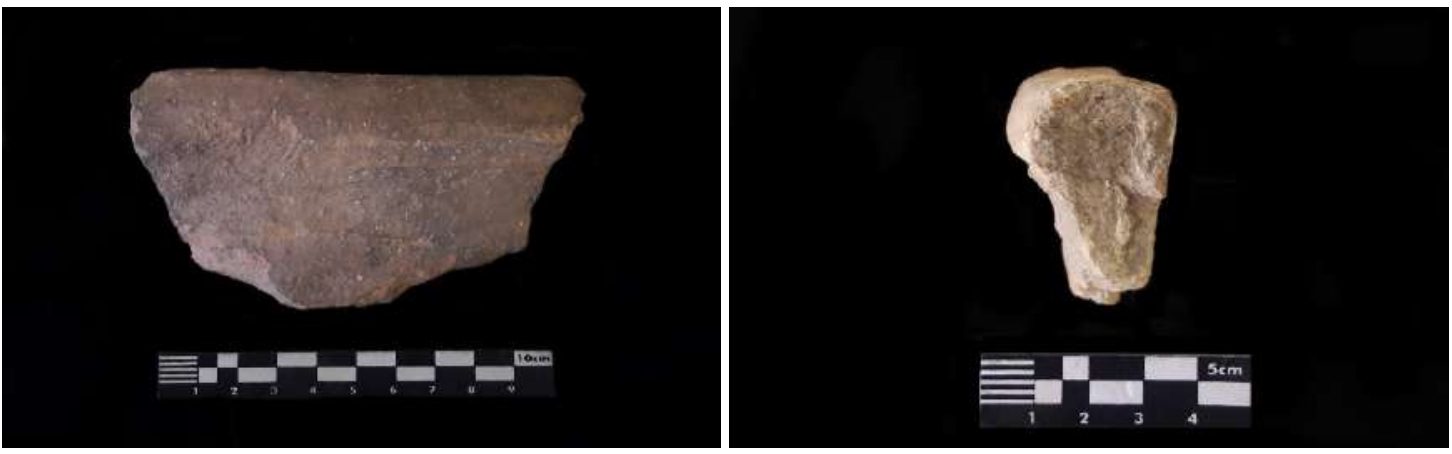

Figura 12: fragmento de borda reforçada externamente (№ de registro IN.363.8)
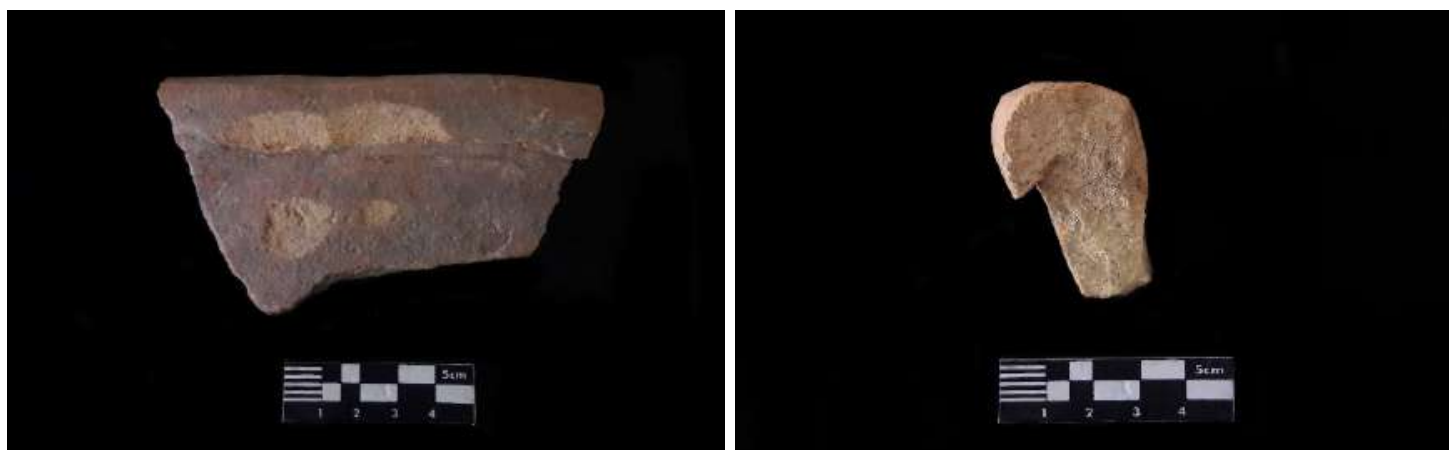

Figura 13: fragmento de borda reforçada externamente (№ de registro IN.668.19)

Especificamente para os fragmentos representados, os diâmetros de abertura da boca dos recipientes foram estimados em $52 \mathrm{~cm}$ (figura 12), e $62 \mathrm{~cm}$ (figura 13), ou seja, enquadram-se na padronização Tipo 2 que compreende as peças maiores. Esse resultado corrobora com a perspectiva, à qual o reforço seria uma característica das peças que, por ventura, comportariam uma maior quantidade de massa de açúcar durante os processos de cristalização e purga. Tais peças configurariam os sinos, utilizados na produção de um açúcar mais bruto, denominado, à época, açúcar Mascavo. A partir de análise métrica concluiu-se que o diâmetro médio de abertura para as amostras do Tipo 2 é de $60 \mathrm{~cm}$.

Informações sobre os sinos identificados nas escavações em Machico, na ilha da Madeira, estão no inventário de Antônio Teixeira, que descreve que o engenho tinha: "2 andaimes de sinos de seis tábuas e noventa fôrmas". Pelo que conta no texto, os sinos seriam uma espécie de fôrmas de argila de grandes dimensões (Sousa, 2006).

Os fragmentos coletados em Machico, depois de submetidos às análises métricas, permitiram concluir que, originalmente, as peças constituíam diâmetros que variavam entre $42 \mathrm{~cm}$ e 55 $\mathrm{cm}$. Os sinos apresentaram bordas de acabamento do tipo emoldurado, provavelmente para facilitar o encaixe nas aberturas dos andaimes de madeira (Sousa, 2006:154). 
Conforme Nunes (2006), o sino seria utilizado para purgar maiores quantidades da massa açucarada, fazendo açúcar de um só cozimento, enquanto que a fôrma, por ser menor, utilizava-se para a produção de um açúcar mais refinado, feito com mais de um cozimento.

Conforme Andrés et al (2017:04) não há um real consenso em relação às medidas das cerâmicas do açúcar, o que pode ser comprovado nos textos que tratam dos recipientes de Atouguia, Portugal, em que alguns objetos teriam média de $44 \mathrm{~cm}$ de altura e boca de $22 \mathrm{~cm}$ de diâmetro, dando indícios de que seriam as fôrmas; e também de sinos, que teriam $66 \mathrm{~cm}$ de altura e $44 \mathrm{~cm}$ de boca. Nas medições efetuadas nos fragmentos de bordas achados em Arucas e Firgas, as medidas dos diâmetros da boca dos objetos definidos como fôrmas flutuam entre os $20 \mathrm{~cm}$ e os $40 \mathrm{~cm}$, com capacidade aproximada de meia arroba, enquanto que os sinos poderiam conter até uma arroba.

De acordo com Oliveira (2010:62) o açúcar submetido a um único processo de purgação era denominado bruto, comercializado em pedaços (torrões); com duas ou mais purgações, obtinha-se o açúcar Demerara. Trata-se de níveis distintos de refino que resultam em um produto mais escuro (açúcar bruto) e um mais claro (açúcar Demerara).

O açúcar purgado em fôrmas maiores (sinos) seria de qualidade inferior ao purgado em fôrmas menores (fôrmas), sendo a utilização dos recipientes maiores compatível com uma produção em escala maior. Assim, entende-se que a utilização das fôrmas remete aos engenhos com capacidade produtiva reduzida, onde, geralmente, a qualidade do produto final era mais cuidada por desejo dos seus proprietários ou por imposição de normas impostas. Uma segunda possibilidade é que as fôrmas de menor dimensão tenham sido utilizadas para a purga do açúcar em ambiente doméstico (Sousa, 2004 apud Lourenço \& Bugalhão, 2006:56).

De acordo com os registros do Livro de Vereações da Câmara Municipal do Funchal (14701472), foi estabelecido um padrão, no qual sete e oito fôrmas correspondessem a uma arroba. Anos mais tarde, um Regimento do Rei D. Manuel I, datado de 27 de Março de 1501, procurou determinar que as fôrmas possuíssem uma medida-padrão, de modo a que seis pães de açúcar correspondessem a uma arroba. O mesmo Regimento dava conta da existência de fôrmas grandes prejudiciais à purgação (Sousa, 2006:25).

Os dados apresentados por Nunes (2006) e por Sousa (2006) foram de grande valia para que as analogias pudessem ser apreciadas entre os relatos históricos e as cerâmicas do engenho Inhamã. Como exemplo, as bordas reforçadas remetendo aos sinos, tendo tal reforço a função 
específica de suportar maior peso de massa de açúcar nas peças encaixadas nas tábuas. Seguindo este raciocínio, aventa-se que, se os sinos eram de fato maiores e utilizados na produção de um açúcar de qualidade inferior, consegue-se inferir, a partir de dados quantitativos, que quanto mais fragmentos deste tipo cerâmico, maior era a produtividade e menor era a pureza do açúcar final.

\section{Considerações finais}

As análises dos fragmentos de bordas e bordas com bojo do sítio arqueológico Engenho Inhamã comprovaram o que muitos pesquisadores retratam em seus trabalhos sobre as cerâmicas do açúcar. As medidas dos objetos cônicos e suas relações com etapas específicas da produção e também com a qualidade do açúcar final produzido são, de certo, muito válidas e afinadas em um contexto lógico. A princípio faz todo sentido inferir que objetos com bordas reforçadas remetam aos sinos, maiores e com capacidade de receber maior quantidade de massa de açúcar a ser cristalizada. Da mesma maneira que as bordas diretas - sem reforço estariam associadas às fôrmas, estas com menor volume e utilizadas para a produção de um açúcar de melhor qualidade. Porém, no engenho Inhamã, em determinado momento, parece que a quantidade de objetos de grande dimensão - os sinos -, era aproximadamente, o dobro da dos objetos menores - as fôrmas, indicando que a produção do engenho Inhamã privilegiava a quantidade em detrimento da qualidade.

Verifica-se nesta coleção que os fragmentos classificados como Tipo 1, ou seja, que possuem medidas diametrais variando entre $18 \mathrm{~cm}$ e $44 \mathrm{~cm}$ somaram 104 unidades; enquanto que os do Tipo 2, com medidas entre $46 \mathrm{~cm}$ e $62 \mathrm{~cm}$ somaram apenas 26 unidades. 0 quantitativo de peças do Tipo 1 em relação ao de peças do Tipo 2 indica que há um predomínio de utensílios de pequenas dimensões - as fôrmas. Nesse caso, não seria prematuro inferir que a produção açucareira do Inhamã privilegiou a produção de um açúcar mais refinado, ainda que em provável escala produtiva de pouca expressão.

Dessa forma, chega-se a resultantes distintas, tanto em relação às quantidades como em relação à qualidade da matéria açucarada pronta para a venda e consumo. Isso aconteceu por que as bordas e as bordas com bojo apresentaram-se com diâmetros de boca com média de 34 $\mathrm{cm}$, remetendo aos recipientes menores, mas que, paradoxalmente, tinham em sua maioria, lábios reforçados. 
Essas questões que envolvem medidas e volumes não podem ser generalizadas, uma vez que podem ser dependentes de variantes externas. Bordas reforçadas em objetos pequenos podem ter fatores diversos que precisam ser reavaliados sob outras perspectivas. Não se pode afirmar, nem tampouco descartar, a possibilidade de que essa realidade esteja atrelada a uma continuidade cultural na produção de utensílios com esta morfologia. Da mesma forma, condições ambientais, tal como a ausência de fontes de argila de boa qualidade, poderiam conduzir os oleiros a produzir artefatos cerâmicos mais reforçados, ainda que pequenos, como forma de garantir maior durabilidade às peças.

Esta pesquisa priorizou o fato de que houve uma presença majoritária de objetos de pequena dimensão utilizados no sítio arqueológico Engenho Inhamã e que, com isso, a qualidade se sobressaía à quantidade do açúcar produzido. Contudo, não se pode desprezar o fato de que ali também se produzia açúcar bruto, uma vez que, das 130 peças que se enquadram nos Tipos 1 e 2, 26 são do Tipo 2, ou seja, de grandes dimensões e relativas aos sinos.

Neste contexto, a quantidade de pequenos recipientes cerâmicos pode superar em até 4 vezes a de grandes recipientes, permitindo inferir que houve uma prevalência por produzir um açúcar mais refinado, submetido à mais de um processo de purgação no sítio arqueológico Engenho Inhamã, provavelmente para atender à uma clientela mais exigente. Entretanto, considera-se os dados ainda preliminares e que se faz necessário a ampliação da pesquisa nessa área.

\section{Referências}

ANDRÉS, P. C. Q.; MEDINA, A. M. J.; MALDONADO, J. M. Z.; MARRERO, J. A. H. 2017. Formas, sinos y porrones: la cerâmica del azúcar em gran canaria, siglos XVI y XVII. XXII Colóquio de Historia CanarioAmericana, España.

ALHEIROS, M. M.; LIMA FILHO, M. F.; MONTEIRO, F. A. J.; OLIVEIRA FILHO, J. S. 1988. Sistemas deposicionais na Formação Barreiras no Nordeste Oriental. In: CONGRESSO BRASILEIRO DE GEOLOGIA, 35., Belém. Anais... Belém: SBG,. v. 2, p. 753-760.

Alheiros, M.M. and Lima Filho, M.F. 1991. A Formação Barreiras. Revisao da faixa sedimentar costeira de Pernambuco, Paraíba e do Rio Grande do Norte. Série Estudos Geológicos, 10, 77-88

CHERQUES, S. 1999. Diccionario do Mar. Rio de Janeiro: Editora Globo.

CLARKE, D.1984. Arqueologia Analítica. Editores Bellaterra, Barcelona.

EIROA, J. J.; BACHILLER GIL, J. A.; PÉREZ, L. C.; MAURANDI, J. L.1999. Nociones de Tecnología e Tipología em Prehistoria. Ariel, Barcelona. 
GOMES, G.. Engenho e Arquitetura. Recife: Fundação Joaquim Nabuco/ Editora Massangana, 2006.

JORDÃO, A. F. 1977. Povoamento, hegemonia e declínio de Goiana. Recife: Pernambuco.

LIMA FILHO, M.; DEMÉTRIO, J. G.; NEUMANN, V. 2005. Estudo da Vulnerabilidade e Proposta de Proteção de Aquíferos da Faixa Costeira Norte de Pernambuco. Relatório Final do CPRH. (Org.) ACCIOLY, A. C. A.; OLINTO, A.; ESPÍNDULA, J. C.

LOURENÇO, S.; BUGALHÃO, J. 2006. A forma de Pão de açúcar da ilha de Berlenga. Mesa Redonda. Lisboa.

MAGNAVITA, C.; LISTO, F.; MÜTZENBERG, D.; TAVARES, B. 2016. Geofísica aplicada à Arqueologia Histórica: um breve estudo de caso no Engenho Inhamã. Igarassu, Pernambuco, Brasil. E book do I Workshop de Geomorfologia e Geoarqueologia do Nordeste. GEQUA. Recife.

MORGADO, P. J. 2006. A cerâmica do açúcar em Aveiro na época moderna. Centro de Estudos de Arqueologia Moderna e Contemporânea- CEAM. n.1. Lisboa, Machico.

NOBRE, J.; FARIA, P.; VELOSA, A. 2017. As paredes de pão-de-açúcar no edifício aveirense. Congresso de reabilitação do Patrimônio - CREPAT. Universidade de Aveiro.

NUNES, N. N. 2006. A terminologia da cerâmica do açúcar de cana. Centro de Estudos de Arqueologia Moderna e Contemporânea- CEAM. Lisboa, Machico.

OLIVEIRA, C. 2018. Relatório Final "Os primeiros engenhos coloniais Sesmaria Jaguaribe - PE". Universidade Federal de Pernambuco. Recife.

OLIVEIRA, C. A.; LARA, P. J. 2012. Relatórios de Atividades de Campo - campanha 01, Engenho Inhamã/Igarassu-PE-BR. Cuadernos de Trabajo. Instituto de Investigaciones Histórico-Sociales. Universidad Veracruzana, 41. Xalapa, Veracruz.

OLIVEIRA, S. P. C. 2010. A cana-de-açúcar nas relações entre Cabo Verde e Brasil. Universidade de Cabo Verde, Departamento de Ciências Sociais e Humanas. Praia.

OLIVEIRA LIMA, M. 1997. Pernambuco: seu desenvolvimento histórico. Recife: Massangana.

PEREIRA, J. R. A construção do território de Igarassu-PE. Instituto do Patrimônio Histórico e Artístico Nacional - IPHAN. s.d.

RIBEIRO FILHO, M. R.; ARAÚJO FILHO, J. C.; RIBEIRO, M. R.; JACOMINE, P. K. T. 2005. Guia de excursão pedológica dos solos da zona da mata pernambucana: solos, sustentabilidade e qualidade ambiental. XXX Congresso Brasileiro de Ciência do Solo. EMBRAPA. Recife.

ROCHA, F.; MORGADO, P. 2014. Mineralogia, matérias-primas e peças cerâmicas. Departamento de Geociências da Universidade de Aveiro. Portugal.

SARMENTO, A. A. 1938. Os escravos na Madeira. Centro de Estudos de Arqueologia Moderna e Contemporânea- CEAM. Funchal.

SIEBERT, C. 1998. História de Pernambuco. FTD. São Paulo.

SIMONSEN, R. C. 1977. História Econômica do Brasil (1500-1820). São Paulo: Nacional.

SANCHES, Celestino Ramos. A cana-de-açúcar em Cabo Verde: Cultivo, Transformação e Comercialização. Praia, Outubro de 2005, 160 p. (Dissertação de Mestrado em História Contemporânea, Instituto Superior de Educação da Universidade Portucalense).

SILVA, G. G. 1997. Engenho e arquitetura. Recife: Fundação Gilberto Freyre. 
SILVA, V. R.; OLIVEIRA, C.; TAVARES, A.; LIMA, J. 2017. Poder e Consumo no Engenho Inhamã, Litoral Norte de Pernambuco, Brasil In: Arqueologia de engenhos: tecnologias, produção e consumo.1 ed.Recife: Editora UFPE, v.2, p. 87-107.

SOBRAL, P.P.D.; TAVARES, A. de A. C.; RIOS, C. 2018. Localização de Sítios Depositários em Pernambuco: Um estudo arqueológico subaquático sob a ótica das atividades comerciais. FUMDHAMentos. vol. XV, n.1, pp.119-140. Recife.

SOUSA, E. D. M. 2005. A cerâmica do açúcar de Machico e do Funchal: dados históricos e arqueológicos para a investigação da tecnologia e da produção açucareira em Portugal. 38th Annual Conference on Historical and Underwater Archaeology (Society for Historical Archaeology). Nova York.

SOUSA, E. D. M.. 2006. A construção do cotidiano nos séculos XV, XVI e XVII. Centro de Estudos de Arqueologia Moderna e Contemporânea- CEAM. Arqueologia da Cidade de Machico. Portugal, 2006. 